\title{
Ameliorative effect of treadmill exercise on cognitive deficits and amyloid-b pathology through the mitophagy in a mouse model of Alzheimer's disease
}

\author{
Dong-hun Choi ${ }^{1}$, Ki-Chun Kwon ${ }^{1}$, Hyun-seoub Eom ${ }^{2}$, Eun-taek $\mathrm{Oh}^{3}$, \& Joon-Yong Cho ${ }^{1}$ * \\ ${ }^{1}$ Korea National Sport University, ${ }^{2}$ Konyang University $\&{ }^{3}$ Woosong University
}

\begin{abstract}
[Purpose] The aim of this study was to investigate the effects of treadmill exercise on mitochondrial quality control in the APP/sw transgenic mice model of Alzheimer's disease(AD). [Methods] The experimental mice were divided into non-tg-control (NTC, $n=10)$, tg-control $(T C, n=10)$, and tg-exercise (TE, $\mathrm{n}=10)$, and treadmill exercise was conducted for 12 weeks $(15 \mathrm{~m} / \mathrm{min}, 60 \mathrm{~min}, 5$ times/week). And then, we measured the cognitive function using MWM and the brain cortex was evaluated to determine whether any changes in the oligomer $A \beta$, apoptotic-related factors, mitophagy and mitochondrial biogenesis. [Results] As a result, treadmill exercise significantly reduced oligomer amyloid and also had a positive effect on proteins (PUMA, Bax, Bcl-2) associated with apoptosis. In addition, through the treadmill exercise, PINK-1 decreased, and increased parkin, showing that active inhibition of mitophagy has been partially relaxed. It has been confirmed that the key autophagy markers LC3 and p62 significantly reduce p62 expression in TE group compared to TC group, and that LC3-II/LC3-I ratio tended to decrease, although not significant, increasing the activity of mitophagy. Next, proteins related to mitochondrial biosynthesis (SIRT-1, PGC-1a, Tfam, and COX-IV) have been identified, and the treadmill exercise has confirmed that the expression of all proteins has increased in part. Finally, cognitive has been shown to improve cognitive by shortening both swimming distance and time through treadmill exercise. [Conclusions] Thus, our finding suggested treadmill exercise alleviates cognitive dysfunction by improving mitochondrial quality control(mitophagy, mitochondrial biogenesis) and neuronal cell death via reducing amyloid accumulation, which may play a role in a preventive strategy for $\mathrm{AD}$.
\end{abstract}

Key words: cognitive function, amyloid, mitophagy, mitochondrial biogenesis, apoptosis

\section{서 론 \\ 미토콘드리아는(mitochondria)는 산화적 인산화 과}

논문 투고일 : 2020. 08. 19.

논문 수정일 : 2020. 09. 15 .

게재 확정일 : 2020. 10. 08.

* 교신저자 : 조준용 (chojy86@knsu.ac.kr).

* 이 논문은 2017년 대한민국 교육부와 한국연구재단의 지원을 받아 수행된 연구임(NRF-2017S1A5A2A01027111).
정을 통해 $90 \%$ 이상의 에너지를 생산할 만큼 세포의 항 상성 유지에 중요한 역할을 담당하는 반면 대부분의 활성 산소(reactive oxygen species: ROS)를 생성시켜 산화 적 스트레스를 일으키는 이중적인 세포 내 소기관이다 [Joselin et al., 2012; Chan, 2006]. 특히, 미토콘드리 아 기능 이상은 비만(obesity), 당뇨(diabetes), 노화 (aging), 암(cancer) 뿐만 아니라 신경퇴행성질환과도 매우 밀접하게 관련되어 있다(Reeve et al., 2008; Naudi et al., 2012: Sanchez-Alvarez et al., 2013). 
이 중 알츠하이머질환(Alzheimer's disease : AD)은 대 표적인 신경퇴행성 질환으로 공통적인 미토콘드리아 기 능 이상이 나타나 산화적 스트레스를 증가시키는 것으로 보고되었다(Rosales-Corral et al., 2012; Joshi et al., 2014; Swerdlow, 2018).

$\mathrm{AD}$ 은 점진적인 기억력과 행동적 장애가 나타나며 유 전적 결함 혹은 다양한 환경적 위험요인에 의해 노령 인 구에서 뿐만 아니라 30 60세와 같이 조기에도 발생되어 심각한 사회적 문제로 대두되고 있다(Ittner, 2011). 지 금까지 $\mathrm{AD}$ 와 관련된 선행연구를 살펴보면 주로 뇌의 변 연 기관인 대뇌피질과 해마에서 베타 아밀로이드 $(\beta$ -amyloid: $\mathrm{A} \beta$ )의 축적과 과 인산화된 세포골격 tau의 인 지기능 저하와 함께 기억력의 감소를 유발하는 것으로 보 고되었다(Selkoe, 2001; Tanzi \& Bertram, 2005). 특 히, $\mathrm{A} \beta$ 는 신경세포사멸을 일으켜 $\mathrm{AD}$ 을 유도하는 유력한 인자로 인식되고 있다(Selkoe, 2001). 현재까지 대부분 의 $\mathrm{AD}$ 치료는 약물치료를 통해 $\mathrm{A} \beta$ 를 감소시켜 병의 진행 을 완화시키거나 지연시키는데 목적이 있었지만 그 효과 는 일시적이고 제한적일 뿐만 아니라 예상치 못한 부작용 이 나타나기 때문에 정기적인 검진을 통해 초기에 발견하 여 치료하는 것을 가장 효과적인 방법으로 제시되었다.

최근 $\mathrm{AD}$ 초기 미토콘드리아 내 $\mathrm{A} \beta$ 의 축적은 산화적 스트레스를 증가시키고 미토콘드리아 관련 효소들의 활 성을 저하시켜 결국 미토콘드리아의 기능이상을 일으키 는 것으로 보고되었다(Manczak et al., 2006; Hansson Petersen et al., 2008; Yao et al., 2011; Calkins et al., 2011; Kumar \& Singh, 2015). 따라서 $A \beta$ 의 축적 으로 인한 비정상적인 미토콘드리아 기능을 개선시키거 나 혹은 알맞게 분해시키는 것이 $\mathrm{AD}$ 을 지연시키고 완화 시킬 수 있는 중요한 요인이라고 생각된다.

미토파지는 비정상적인 미토콘드리아를 분해하는 기전 으로 PTEN-induced putative kinase 1(PINK1)-Parkin 기전을 통해 선택적으로 미토콘드리아를 분해하여 세포 의 질적 수준을 유지하는 중요한 시스템으로 알려져 있다 (Youle \& van der Bliek, 2012; Ding \& Yin, 2012; Lazarou et al., 2015; Whitworth \& Pallanck, 2017). 하지만 $\mathrm{AD}$ 동물모델의 뇌에서 PINK-1과 Parkin의 발 현이 유의하게 감소하는 것으로 나타나 미토파지의 활성 감소가 보고되었다(Chen \& Chan, 2009). 또한,
Parkin의 발현을 억제시킨 Knock-out 마우스에서 $\mathrm{A} \beta$ 의 축적이 증가되었지만 Parkin의 발현을 증가시킨 후 미토 파지의 활성 증가되고 이는 $A \beta$ 를 감소시켜 신경세포 생 존을 유지한 것으로 보고되었다(Rosen et al., 2010; Khandelwal, 2011). 따라서 PINK1/Parkin pathway 를 활성화시키는 것은 $A \beta$ 를 감소시킬 뿐만 아니라 손상 된 미토콘드리아의 제거를 증가시켜 결과적으로 미토콘 드리아 항상성을 개선시킬 수 있다고 생각된다.

운동은 뇌의 기억과 학습능력에 긍정적인 영향을 주는 뇌유래신경영양인자(Brain-derived neurotrophic factor), 신경세포사멸 억제, 신경재생(neurogenesis) 등을 통해 신경퇴행성 질환에 긍정적인 영향을 미치는 것 으로 알려져 있다(Mattson \& Magnus 2006; Nichol et al., 2007; Choi et al., 2018; Lourenco et al., 2019). 특히, 지구성 운동은 $\mathrm{AD}$ 의 $\mathrm{A} \beta$ 를 현저하게 감소시켜 산화 적 스트레스 완화와 함께 인지기능을 향상시키는 것으로 보고되었지만 (Cho et al., 2010, Kang et al., 2013; Choi et al., 2014, Koo et al., 2017), 운동에 의한 AB 감소가 어떠한 기전으로 진행되는지 확실하게 밝혀져 있 지 않다.

여러 가지 운동 중 트레드밀 운동은 미토콘드리아 기 능 및 오토파지의 활성을 증가시켜 비정상적인 단백질을 분해하고 세포의 항상성을 유지하여 학습 및 기억 능력에 긍정적인 것으로 알려져 있다(Vainshtein et al., 2015; Marques-Aleixo et al., 2015; Marques-Aleixo et al., 2016; Luo et al., 2017). 특히 4주간의 지구성 운동은 미토콘드리아 생합성과 미토파지에 관련된 단백질을 증 가시켜 운동에 의한 골격근의 적응에 긍정적인 영향을 미 친다고 보고하였다(Lira et al., 2013). Goncalves et al. (2016)은 고지방식으로 비만을 유도한 쥐를 대상으로 9주간 트레드밀 운동 $(60 \mathrm{~min} /$ day, $15 \mathrm{~m} / \mathrm{min}, 5$ days/week)을 수행한 결과 미토파지 관련 핵심 단백질 인 PINK1과 Parkin의 발현을 증가시켜 미토파지의 활 성 보고하였다. 또한 Vainshtein et al.(2015)은 일회성 운동이 parkin, Dynamin-relatived protein 1(Drp1), peroxisome proliferator-activated receptor $\gamma$ coactivator $1 \alpha(\mathrm{PGC}-1 \alpha)$ 의 발현을 증가시켜 미토콘드 리아 생합성과 미토파지에 중요한 역할을 담당하는 것으 로 제시하였다. 이처럼 운동에 의한 미토파지의 활성은 
세포 내 항상성을 유지하는데 필수적인 것으로 알려져 있 지만 지금까지의 선행연구 대부분은 정상적인 상태에서 나타나는 미토파지의 기능을 확인한 연구로 $\mathrm{AD}$ 와 관련 된 미토파지와의 관련성을 살펴본 연구는 부족한 실정이 다. 따라서 $\mathrm{AD}$ 의 미토파지 활성이 운동을 통해 증가되는 것을 확인하고 이와 관련된 $\mathrm{A} \beta$ 의 감소를 확인한다면 운 동에 의한 인지기능 개선과 $\mathrm{A} \beta$ 의 감소 기전을 과학적으 로 증명할 수 있는 의미있는 연구라고 생각된다. 따라서 본 연구의 목적은 $\mathrm{AD}$ 동물 모델을 대상으로 12 주간의 트 레드밀 운동이 미토콘드리아 항상성 기전에 미치는 영향 을 확인하기 위해 미토파지와 미토콘드리아 생합성 관련 단백질을 분석하여 이를 통해 $\mathrm{A} \beta$ 감소와 인지기능이 개 선되는지 확인하는데 있다.

\section{연구방법}

\section{실험동물}

알츠하이머 형질전환 생쥐(NSE/APPsw transgenic mice, $n=20)$ 와 비 형질전환 생쥐 $(n=10)$ 를 식약처 동물 실험실에서 분양받았으며 $\mathrm{K}$ 대학교 동물사육실(온도 20 $\pm 3^{\circ} \mathrm{C}$, 습도 $50 \%$, 주간 점등:08:00-20:00, 야간 소등: 20:00-08:00)에서 사육하였다. 집단은 Non-Transgeniccontrol (NTC: 10마리), Transgenic-control (TC: 10 마리) 및 Transgenic-exercise(TE: 10마리)로 구분하 였으며 모든 실험은 $\mathrm{K}$ 대학교 동물실험연구 윤리위원회 의 승인(KNSU-IACUC-2017-12)을 받았다.

\section{운동 프로그램}

트레드밀 운동(treadmill exercise)은 rodent 트레드 밀 기구(8Lanes, Daemyung Scientific Co, Ltd, Korea)를 이용하였고, 사전 기기에 대한 적응을 위해 일 주일간 실시하였다 $(10 \mathrm{~min}, 10 \mathrm{~m} / \mathrm{min}, 7 \mathrm{day} / \mathrm{week})$. 이 후 본 운동에서는 $\mathrm{AD}$ 생쥐를 대상으로 트레드밀 운동을 실시한 Koo et al.(2017)의 프로그램을 참고하여 12주 간 $(15 \mathrm{~m} / \mathrm{min}, 60 \mathrm{~min}, 5$ day/week) 실시하였다.

\section{수중미로검사}

$\mathrm{AD}$ 생쥐를 대상으로 12 주간의 트레드밀 운동이 종료 된 후 수중미로검사(morris water maze : MWM)를 실 시하여 인지기능 능력을 평가하였다(Kelley et al., 2011). 먼저 컴퓨터 프로그램을 이용한 카메라 (SMART-LD)로 MWM 중 나타나는 수영 거리와 시간을 측정한 후 SMART-CS 프로그램(Panlab, Barcelona, Spain)을 이용하여 분석하였다. MWM 도구는 지름 $1.5 \mathrm{~m} \times$ 높이 $40 \mathrm{~cm}$ 의 원형 수조에 도피대(지름 $12 \mathrm{~cm} \times 30 \mathrm{~cm}$ )를 수면보다 1 2cm 정도 낮게 설치한 후 $23^{\circ} \mathrm{C}$ 물과 함께 탈지분유를 첨가하여 도피대가 보이지 않게 하였다. MWM는 총 6 일간에 걸쳐 수행하였으며 처 음 5 일간은 2 회씩 보이지 않는 도피대를 인지할 수 있도 록 훈련하고 마지막 6 일째 인지능력 평가는 도피대를 제 거한 후 동일한 출발지점에서 시작하여 60 초 동안 도피 대를 2회 지나간 경우를 종료시점으로 정하였고, 그때의 시간과 거리를 실험 데이터로 사용하였다.

\section{뇌 적출}

12 주간의 트레드밀 운동과 수중미로검사가 종료된 12 시간 후 pentobarbital sodium $(50 \mathrm{mg} / \mathrm{kg})$ 을 이용하여 마취하고, 흉강을 열어 좌심실을 통하여 $50 \mathrm{mM}$ 인산염 완충 식염수(phosphoate buffer saline, PBS)를 5 분 동 안 주입하였다. 이후 4\% paraformaldehyde (PFA) 고 정액을 관류한 후 뇌를 적출하고 다시 $4 \% \mathrm{PFA}$ 고정액에 담아서 $4^{\circ} \mathrm{C}$ 에서 12 시간 침전시켜 고정하였다. 다음으로 조직을 $30 \%$ Sucrose 용액에서 5 일 동안 침전시킨 후 freezing microtome (Leica, Nussloch, Germany)를 이 용하여 $40 \mu \mathrm{m}$ 두께의 연속관상 절편을 제작하였다. 단백 질 분석을 위해 뇌 적출 후 대뇌피질을 분리하여 분석시 까지 $-80^{\circ} \mathrm{C}$ 초저온냉동고에 보관하였다.

\section{Western blotting}

집단별로 분리된 대뇌피질을 Bradford(1976)법에 따 라 단백질을 정량한 후 $20 \sim 30 \mu \mathrm{g}$ 으로 $\quad 10-12 \%$ SDS-Polyacrylamide gel에 전기영동 하였다. 다음 membrane으로 전이시키기 위해 transfer를 실시하고 
난 후 membrane에 폰슈(Ponceau S)를 1분 발색하여 총 단백질이 잘 전이되었는지와 단백질 정량이 알맞게 분 주되었는지 확인하였다. 이후 3 분간 정제된 물 $(\mathrm{DW})$ 로 membrane에 염색된 Ponceau S 제거하고 5\% BSA가 첨가된 $1 \mathrm{xTBS}-\mathrm{T}$ 용액에 membrane을 90 분간 상온에 반응(blocking)시켰다. 1차 항체 $\beta$-amyloid(sc-28365, Santa cruz), PUMA(sc-374223, Santa cruz), Bcl-2(A0208, Abcronal), Bax(A7626, Abcronal), PINK-1(sc-517353, Santa cruz), Parkin(sc-32282, Santa cruz), LC3(\#12741, cell sinaling), p62(A7758, Abcronal), SIRT1(sc-19857, Santa

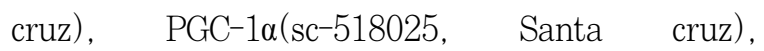
Tfam(A1926, Abcronal), COX-IV(sc-292052, Santa cruz)는 $4^{\circ} \mathrm{C}$ 에서 (12시간 이상) 반응시켰다. 이후 $1 \mathrm{xTBS}-\mathrm{T}$ 용액으로 8분간 4회 세척 후 2차 항체와 상온 에서 90분간 반응시킨 후에 다시 $1 \mathrm{xTBS}-\mathrm{T}$ 용액으로 8분 간 4회 세척 후, ECL 용액 (WBLUF0100; Millipore, $\mathrm{USA}$ )에 membrane을 1 분간 반응시킨 후 이미지 분석 시스템(ChemiDoc XRS System, Bio-Rad, USA)을 이 용하여 촬영하였다. 촬영 후 얻어진 단백질 발현 정도는 Quantity One 1-D Analysis Software(Bio-Rad, USA)를 사용하여 최종 단백질량을 산출하였다.

\section{Immunohistochemistry}

면역조직화학염색은 통상적인 조직표본제작법에 따라 파라핀 포매한 후 $5-6 \mu \mathrm{m}$ 로 절편한 후 $60^{\circ} \mathrm{C}$ 오븐에서 90-120분간 방치 한 후 Xylene으로 조직 내에 존재하는 파라핀을 제거하고, $\mathrm{PBS}$ 로 5 분간 4 회 세척 한 후 $3 \%$ 혈 청으로 $37^{\circ} \mathrm{C}$ 에서 40 분간 blocking하였다. 1차 항체 (amyloid, 6E10, covance)를 $4^{\circ} \mathrm{C}$ 에서 overnight(16시 간)하고 $\mathrm{PBS}$ 로 3 회 세척 한 후 2 차 항체를 실온에서 40 분간 반응 시키고 diaminobenzidine( $\mathrm{DAB}$, Vector, $\mathrm{USA})$ 으로 반응시킨 후 봉입 한 후 광학현미경 (DM2500, Leica, Germany) 로 관찰하였다.

\section{자료처리}

수집된 자료는 SPSS Statistics 25.0 통계 프로그램
을 이용하여 각 변인들에 대한 평균표준편차 $(\mathrm{Mean} \pm \mathrm{SD})$ 로 산출하였으며 각 집단 및 기간에 따른 변 인들 차이를 확인하기 위해서 일원량분석(One way ANOVA)을 실시하였다. 또한, 각각의 차이를 구체적으 로 확인하기 위해 Bonferroni를 이용하여 사후 검증을 실 시하였다. 모든 분석의 통계적 유의수준은 $\alpha=.05$ 로 설정 하였다.

\section{연구결과}

\section{트레드밀 운동에 의한 아밀로이드 단백질과 신경세 포사멸에 미치는 영향}

운동에 의한 인지기능 메커니즘을 구체적으로 확인하 기 위해 $\mathrm{AD}$ 병리학적 특징인 $\mathrm{AB}$ 발현과 그와 관련된 신경 세포사멸을 확인하였다(Figure 1). 먼저 아밀로이드 전구 단백질 (amyloid precursor protein: $\mathrm{APP}$ )은 집단 간 유 의한 차이가 나타나지 않았다 $(\mathrm{F}(2,15)=3.594, p=.053$, Figure $1 B$ ). oligomer $A \beta$ 과 oligomer $A \beta / A P P$ ratio는 집단 간 유의한 차이(oligomer $\mathrm{A} \beta: \mathrm{F}(2,15)=26.120$, $p=.001$; oligomer $\mathrm{A} \beta / \mathrm{APP}$ ratio: $\mathrm{F}(2,15)=17.264$, $p=.001)$ 가 나타나 사후 검증을 실시한 결과 NTC 집단과 비교하여 $\mathrm{TC}$ 집단에서 유의하게 증가하였다 $(p=.001$, respectively, Figure 1B). 또한 면역조직화학염색에서 도 $\mathrm{TC}$ 집단이 $\mathrm{NTC}$ 집단과 비교하여 두드러지게 $\mathrm{A \beta}$ (6E10)가 염색된 것으로 나타났다(Figure $1 \mathrm{E}$ ). 다음으 로 신경세포사멸과 관련된 단백질을 확인한 결과 세포사 멸 촉진 단백질인 p53 upregulated modulator of apoptosis(PUMA)와 Bcl-2-associated X $\operatorname{protein}(\mathrm{Bax})$, 세포사멸 억제 단백질인 $\mathrm{B}$-cell lymphoma 2(Bcl-2)와 $\mathrm{Bax} / \mathrm{Bcl}-2$ ratio에서 집단 간 유 의한 차이 $(\mathrm{PUMA}: \mathrm{F}(2,15)=63.974, p=.001 ; \mathrm{BAX}$ : $\mathrm{F}(2,15)=27.528, p=.001 ; \mathrm{Bcl}-2: \mathrm{F}(2,15)=37.277$, $p=.001 ; \mathrm{Bax} / \mathrm{Bcl}-2$ ratio: $\mathrm{F}(2,15)=64.401, p=.001$, Figure $1 \mathrm{D}$ )가 나타나 사후검증을 실시한 결과 TC 집단이 NTC 집단과 비교하여 PUMA, Bax와 $\mathrm{Bax} / \mathrm{Bcl}-2$ ratio는 유의하게 증가하였고, $\mathrm{Bcl}-2$ 는 유의하게 감소하였다 ( $p=.001$, respectively). 하지만 oligomer $\mathrm{A} \beta$ 과 
oligomer AB/APP ratio는 트레드밀 운동을 통해 TC 집 단보다 유의하게 감소되었으며 ( $p=.001$, respectively), $\mathrm{IHC}$ 의 결과에서도 트레드밀 운동에 의한 염색 수준이 감
소하였다. 또한, PUMA, $\mathrm{Bax}$ 및 $\mathrm{Bax} / \mathrm{Bcl}-2$ $\operatorname{ratio}(p=.001$, respectively) 수준이 TC 집단에 비해 감 소하였고, $\mathrm{Bcl}-2$ 수준은 증가하였다 $(p=.001)$.

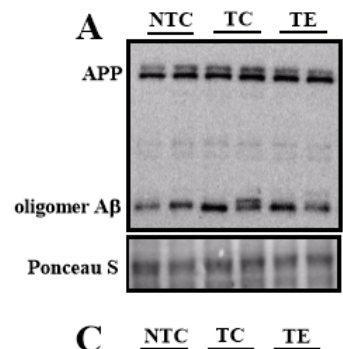

B

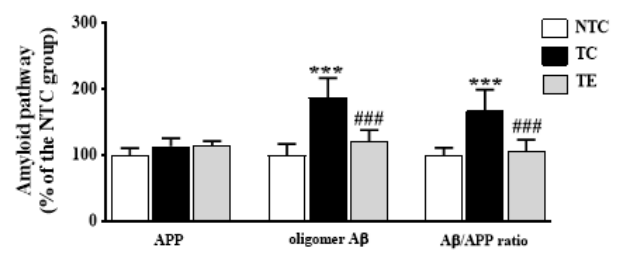

D

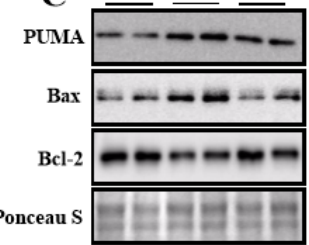

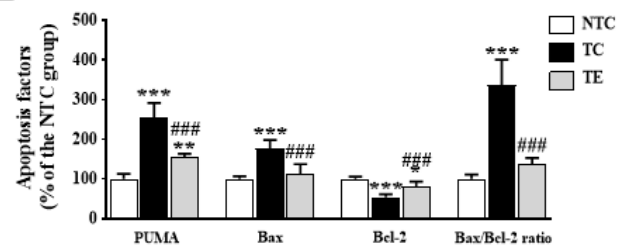

E

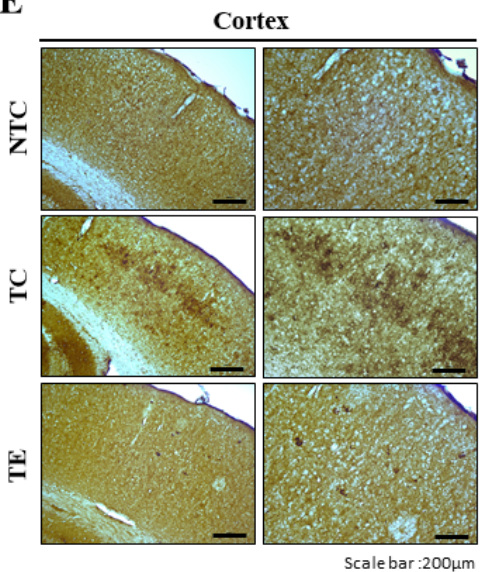

Fig. 1. Treadmill exercise reduces Amyloidgenic pathway and apoptosis-related factors in the cortex of APPsw AD model. A, B) Representative blot of western bands and densitometry quantification for APP, oligomer A , and oligomer A $/ \mathrm{APP}$ ratio. C) Representative blot of western bands and densitometry quantification for PUMA, Bax, Bcl-2, Bax/Bcl-2 ratio. E) Immunohistochemical analysis A $\beta$ (6E10) in the cortex from each group are shown(n=4/group). Values are expressed to $100 \%$ for levels of NTC group. Ponceau $\mathrm{S}$ was probed as housekeeping gene. All bars shown represent the means $\pm \mathrm{SD}$ (n=6/group). A Bonferroni post-doc test: ${ }^{*} p<.05,{ }^{* *} p<.01,{ }^{* * * *} p<.001$, compared to the NTC group; \#p<.05, \#\#p<.01, \#\#p<.001 compared to the TC group. Non tg-control (NTC), tg-control (TC), and tg-exercise (TE).

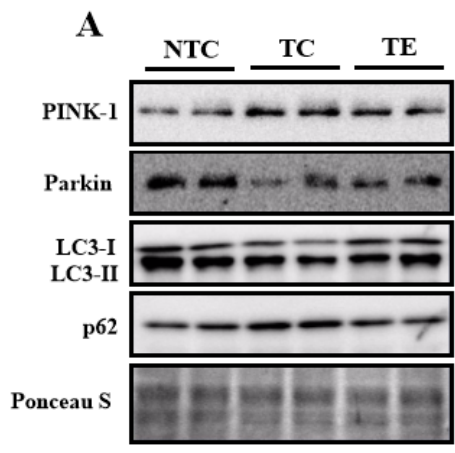

B

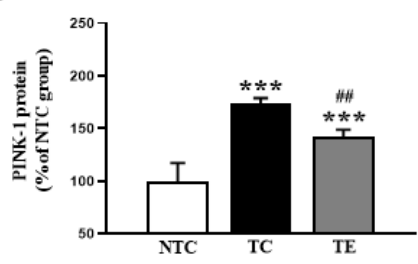

$\mathbf{D}$

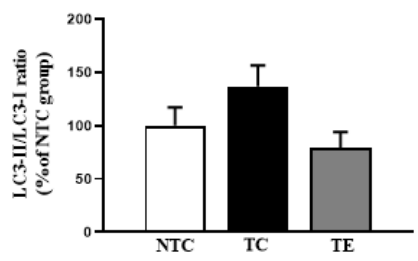

C

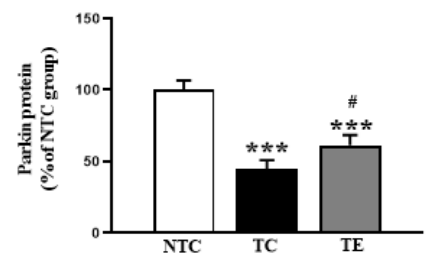

$\mathbf{E}$

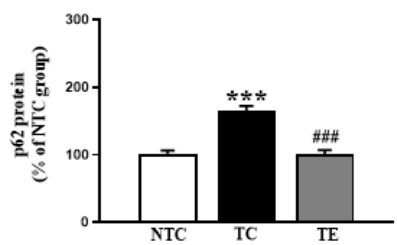

Fig. 2. Treadmill exercise activates the level of mitophagy-related proteins in the cortex of APPsw AD model. A) Representative blot of western bands for PINK-1, Parkin, LC3-II/LC3-I ratio, and p62 in the cortex. B-E) Densitometry quantification of the PINK-1, Parkin, LC3-II/LC3-I ratio, and p62 in the cortex. Values are expressed to $100 \%$ for levels of NTC group. All bars shown represent the means \pm SD ( $\mathrm{n}=6$ /group). Ponceau $\mathrm{S}$ was probed as housekeeping gene. A Bonferroni post-doc test: ${ }^{*} p<.05,{ }^{* *} p<.01,{ }^{* * *} p<.001$, compared to the NTC group; $\# p<.05$, $\#$ \#p<.01, \#\#\#p<.001 compared to the TC group. Non tg-control (NTC), tg-control (TC), and tg-exercise (TE). 


\section{트레드밀 운동에 의한 미토파지 기전 변화}

12 주간의 트레드밀 운동 후 미토콘드리아를 분해하는 미토파지 관련 단백질을 분석하였다〈Figure 2〉. 먼저 미 토파지의 개시인자로 알려진 PINK-1과 Parkin의 발현 은 집단 간 유의한 차이 $(\mathrm{PINK}-1: \mathrm{F}(2,15)=67.675$, $p=.001$; Parkin: $\mathrm{F}(2,15)=47.608, p=.001$, Figure $2 \mathrm{~B}-\mathrm{C}$ )가 나타나 사후 검증을 실시한 결과 $\mathrm{NTC}$ 집단과 비교하여 TC 집단에서 PINK-1은 유의한 증가가 나타났 고, Parkin은 유의하게 감소하였다 $(p=.001$, respectively). 하지만 트레드밀 운동은 PINK-1을 TC 집단에 비해 유의하게 감소시키고 $(p=.002)$, Parkin은 유의하게 증가시켰다 $(p=.038)$. 또한, 미토파지 이후 과 정인 LC3-II/LC3-I ratio와 p62 발현 수준을 확인하였 다. 오토파지의 핵심 마커인 LC3-II/LC3-I ratio의 발현 을 확인한 결과 집단 간 유의한 차이가 나타나지 않았다 (LC3-II/LC3-I ratio: $\mathrm{F}(2,15)=3.546, \quad p=.055$, Figure 2D). p62의 경우 집단 간 유의한 차이 $(\mathrm{F}(2,15)=83.879, p=.001$, Figure $2 \mathrm{E})$ 가 나타나 사 후검증을 실시한 결과 $\mathrm{TC}$ 집단은 NTC 집단과 비교하여 유의하게 증가된 것으로 나타났지만 $(p=.001)$, 트레드 밀 운동을 실시한 $\mathrm{TE}$ 집단에서 $\mathrm{TC}$ 집단과 비교하여 유의
하게 감소된 것으로 나타났다 $(p=.001)$.

\section{트레드밀 운동에 의한 미토콘드리아 생합성의 변화}

12 주간의 트레드밀 운동 후 대뇌피질의 미토콘드리아 생합성과 관련된 단백질을 확인하였다〈Figure 3〉. SIRT-1의 발현은 집단 간 유의한 차이(SIRT-1: $\mathrm{F}(2,15)=10.492, p=.001$, Figure 3B)가 나타나 사후 검증을 실시한 결과 $\mathrm{NTC}$ 집단과 비교하여 $\mathrm{TC}$ 집단에서 유의하게 감소된 것으로 나타났지만 $(p=.001)$, 운동을 실시한 $\mathrm{TE}$ 집단에서 유의한 차이가 나타나지 않았다 $(p=.071) . \mathrm{SIRT}-1$ 의 하위 기전인 $\mathrm{PGC}-1 \alpha$ 와 Tfam의 발현은 집단 간 유의한 차이 $(\mathrm{PGC}-1 \alpha: \mathrm{F}(2,15)=$ $32.014, p=.001$, Tfam: $\mathrm{F}(2,15)=27.815, p=.001$, Figure $3 \mathrm{C}-\mathrm{D}$ ) 가 나타나 사후 검증을 실시한 결과 NTC 집단과 비교하여 $\mathrm{TC}$ 집단에서 유의하게 감소된 것으로 나타났지만( $p=.001$, respectively), 트레드밀 운동을 실시한 $\mathrm{TE}$ 집단에서 $\mathrm{TC}$ 집단에 비해 통계적으로 유의하 게 증가된 것으로 나타났다(PGC- $1 \alpha: p=.047$, Tfam: $p=.004)$. 마지막으로 전자전달계 핵심 효소인 COX-IV 의 발현은 집단 간 유의한 차이 $(\mathrm{F}(2,15)=9.989$, $p=.002$, Figure $3 \mathrm{E})$ 가 나타나 사후 검증을 실시한 결과

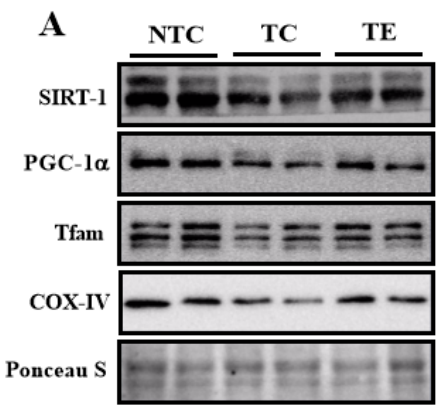

B

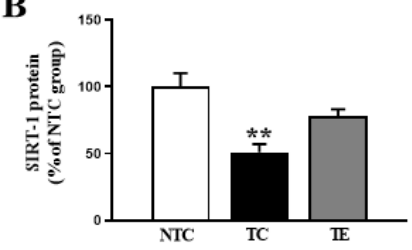

D

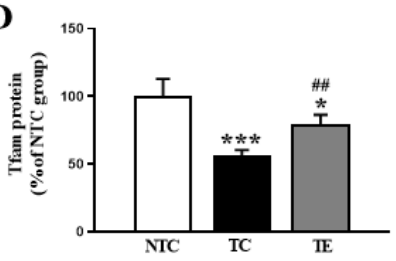

C

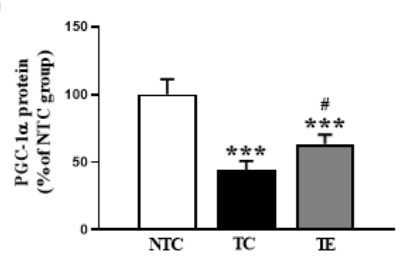

$\mathbf{E}$

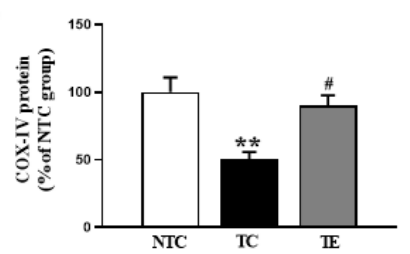

Fig. 3. Treadmill exercise activates the level of mitochondrial biogenesis-related factors in the cortex of APPsw AD model. A) Representative blot of western bands for SIRT-1, PGC-1 $\alpha$, Tfam, and COX-IV in the cortex. B-E) Densitometry quantification of the SIRT-1, PGC-1 $\alpha$, Tfam, and COX-IV in the cortex. Values are expressed to $100 \%$ for levels of NTC group. All bars shown represent the means $\pm \mathrm{SD}$ ( $\mathrm{n}=6 /$ group). Ponceau $\mathrm{S}$

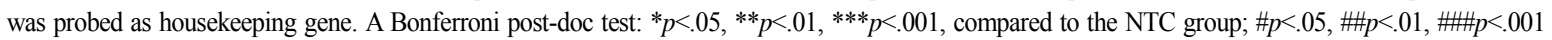
compared to the TC group. Non tg-control (NTC), tg-control (TC), and tg-exercise (TE). 
A

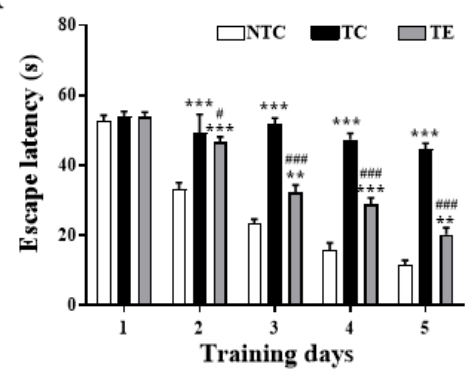

C

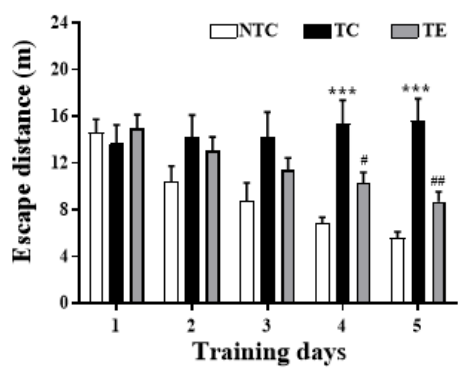

B

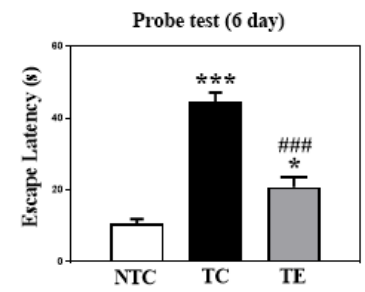

D

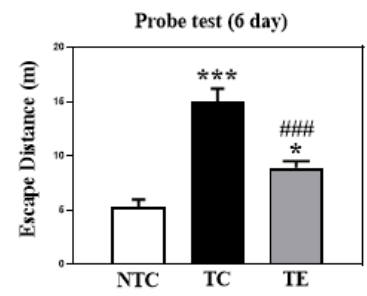

Fig. 4. Treadmill exercise improves cognitive deficits in the APPsw AD model. A) Escape latency during 5 days of training days ( 5 days). B) Escape latency of probe test. C) Escape distance during 5 days of training days (5 days). D) Escape distance of probe test. All bars shown represent the means $\pm \operatorname{SEM}\left(\mathrm{n}=10\right.$ /group). ABonferroni post-doc test: ${ }^{*} p<.05,{ }^{* *} p<.01,{ }^{* * *} p<.001$, compared

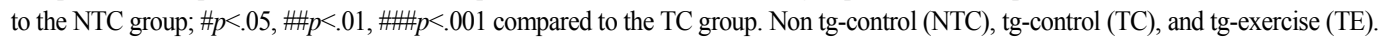

$\mathrm{NTC}$ 집단과 비교하여 $\mathrm{TC}$ 집단에서 유의하게 감소된 것 으로 나타났지만 $(p=.002)$, 운동을 실시한 TE 집단에서 $\mathrm{TC}$ 집단에 비해 통계적으로 유의하게 증가된 것으로 나 타났다 $(p=.012)$.

\section{트레드밀 운동에 의한 인지기능의 변화}

12 주간의 트레드밀 운동이 인지기능에 미치는 영향을 확인하기 위해 수중미로검사를 실시하였다〈Figure 4〉. 먼 저 5 일간의 트레이닝 기간 동안 수영 시간은 $2-5$ 일간 집단 간 유의한 차이 ( 2 days: $\mathrm{F}(2,27)=36.731, p=.001 ; 3$ days: $\mathrm{F}(2,27)=69.607, p=.001 ; 4$ days: $\mathrm{F}(2,27)=$ 68.027, $p=.001 ; 5$ days: $\mathrm{F}(2,27)=114.511, p=.001$, Figure $4 \mathrm{~A}$ )가 나타나 사후검증을 실시한 결과 TC 집단은 $\mathrm{NTC}$ 집단과 비교하여 수영 시간이 유의하게 증가하였다 ( $p=.001$, respectively). 또한, 수영 거리에서도 4 일과 5 일차에서 유의한 차이(4 days: $\mathrm{F}(2,27)=10.604$, $p=.001 ; 5$ days: $\mathrm{F}(2,27)=16.924, p=.001$, Figure
$4 \mathrm{C})$ 가 나타나 사후 검증을 실시한 결과 TC 집단이 NTC 집 단과 비교하여 수영 거리가 유의하게 증가하였다 $(\mathrm{p}=.001$, respectively). 한편 12 주간 트레드밀 운동을 실시한 TE 집단에서는 $\mathrm{TC}$ 집단과 비교하여 수영 시간과 $(2$ days: $p=.025,3-4$ days: $p=.001$, Figure $4 \mathrm{~A}$ ), 수영 거리가(4 days: $p=.035,5$ days: $p=.002$, Figure 4C) 유의하게 감소하였다. 마지막으로 훈련의 효과를 확인하기 위해 5 일간 의 트레이닝 후 최종 인지기능 능력을 측정한 결과(Figure $4 \mathrm{~B}, \mathrm{D})$ 트레이닝 기간과 유사하게 TC 집단이 NTC 집단과 비교하여 수영 시간과 수영 거리 $(p=.001$, respectively) 가 유의하게 증가한 것으로 나타났지만, 트레드밀 운동을 통해 감소하는 결과가 나타났다 ( $p=.001$, respectively).

\section{논 의}

본 연구에서는 12 주간의 트레드밀 운동이 $\mathrm{AD}$ 생쥐에 서 미토파지와 미토콘드리아 생합성 기전에 따라 인지기 
능과 $\mathrm{A} \beta$ 의 변화를 분석하였고 흥미로운 연구 결과를 얻 을 수 있었다. 첫째, 트레드밀 운동은 $\mathrm{AD}$ 생쥐의 대뇌피 질에서 병리학적 특징인 $\mathrm{A} \beta$ 를 감소시켜 세포사멸의 억제 와 인지기능의 개선을 확인하였다. 둘째, 트레드밀 운동 은 미토파지의 개시인자인 PINK-1의 감소와 parkin의 증가로 미토파지의 활성이 개선되었으며, 오토파지의 주 요 마커인 LC3-II/LC3-I ratio에서 유의한 차이는 나타 나지 않았지만 감소하는 경향이 나타났으며, p62가 유의 하게 감소한 것으로 미토파지의 활성이 증가된 것을 확인 하였다. 셋째, 트레드밀 운동은 미토콘드리아 생합성과 관련된 SIRT-1 발현에서 유의한 차이는 나타나지 않았 지만 긍정적인 경향이 나타났으며, PGC- $1 \alpha$, Tfam 및 $\mathrm{COX}-\mathrm{IV}$ 를 유의하게 증가시켰다. 이러한 결과는 트레드 밀 운동이 알츠하이머 질환에서 미토파지와 미토콘드리 아 생합성을 활성화시켜 $\mathrm{A} \beta$ 의 축적과 세포사멸을 억제하 는데 관련이 있음을 입증하였다.

최근까지 운동에 의한 인지기능 개선은 일부 연구에서 진행되어 그 효과의 중요성이 보고되었지만 어떠한 기전 으로 개선되는지 정확하게 밝혀진 바가 없다. 본 연구에 서는 알츠하이머 질환 생쥐에게 많이 사용되는 트레드밀 운동을 실시하였으며, 미토콘드리아 기능 개선, 면역과 염증 완화 등의 결과를 보고한 선행연구를 참고하여 지구 성 운동을 실시하였다(Choi et al., 2014; Koo et al., 2017; Cho et al., 2010). 따라서 운동에 의한 인지기능 메커니즘을 구체적으로 확인하기 위해 $\mathrm{AD}$ 병리학적 특 징인 $\mathrm{A} \beta$ 발현과 그와 관련된 신경세포사멸을 확인하였 다.

먼저 아밀로이드 전구 단백질(amyloid precursor protein: APP)은 막 사이 공간에 위치하여 $\alpha, \beta$ 및 $\gamma$ 효소 에 의해 $\mathrm{A} \beta$ 를 생성시키거나 혹은 생성되지 않는 전구 단 백질로 알려져 있다(Wilkins et al., 2018). 주목할 점은 분절 효소들에 의해 잘려진 $\mathrm{APP}$ 의 부산물인 $\mathrm{A \beta}$ 이 축적 되면 신경세포사멸을 유도하기 때문에 본 연구에서도 $\mathrm{A} \beta$ 발현 수준을 확인하였다. oligomer $A \beta$ 와 oligomer $A \beta$ /APP ratio를 분석한 결과 NTC 집단과 비교하여 TC 집 단에서 유의하게 증가된 것으로 나타났다. 또한 면역조직 화학염색에서도 $\mathrm{TC}$ 집단이 NTC 집단과 비교하여 두드 러지게 $\mathrm{A} \beta(6 \mathrm{E} 10)$ 가 염색된 것으로 나타났다. 이러한 결 과는 $\mathrm{AD}$ 모델에서 $\mathrm{A} \beta$ 의 축적을 보고한 선행연구와 일치
하는 결과를 나타냈다(Zhao et al., 2018; Zhao et al., 2020).

또한, 신경세포사멸과 관련된 단백질을 확인한 결과 $\mathrm{A}$ $\beta$ 의 축적이 나타난 $\mathrm{TC}$ 집단이 NTC 집단과 비교하여 세 포사멸 촉진 단백질인 p53 upregulated modulator of apoptosis(PUMA)와 Bcl-2-associated X protein(Bax) 이 유의하게 증가하였고 세포사멸 억제 단백질인 B-cell lymphoma 2(Bcl-2)는 유의하게 감소한 것으로 나타났 다. 이는 선행연구에서 제시한 것과 유사하게 $\mathrm{A \beta}$ 이 축적 에 의한 신경세포사멸이 진행되었다는 것을 의미한다 (Wang et al., 2020).

트레드밀 운동을 통해 oligomer $A \beta$ 과 oligomer $A \beta$ /APP ratio는 유의하게 감소하였으며, $\mathrm{IHC}$ 의 결과에서 도 염색 수준이 감소한 것으로 나타나 운동에 의한 $\mathrm{A} \beta$ 의 감소를 보고한 선행연구와 일치하는 결과를 나타냈다 (Zhao et al., 2018; Zhao et al., 2020). 이러한 감소는 결국 PUMA, Bax 및 $\mathrm{Bax} / \mathrm{Bcl}-2$ ratio의 발현을 감소시 키고, Bcl-2 발현을 증가시켜 신경세포의 사멸을 완화시 킨 것으로 나타났다. 따라서 트레드밀 운동은 $\mathrm{A} \beta$ 을 감소 시키고 신경세포사멸을 억제시켜 일부 인지기능을 개선 시킨 것으로 생각된다.

하지만 운동이 어떠한 기전으로 $\mathrm{A} \beta$ 를 감소시킬 수 있 는지 확실히 밝혀져 있지 않다. 최근 $\mathrm{AD}$ 에서 미토콘드리 아 기능 이상이 발병 초기에 나타나며 이는 $\mathrm{A \beta}$ 의 축적과 매우 밀접한 관련이 있는 것으로 보고하였다(Choi et al., 2013; Zhao et al., 2018).

미토파지는 $\mathrm{AD}$ 등 신경퇴행성 뇌질환에서 손상된 미토콘 드리아 제거에 parkin의 개입이 증명되면서 PINK1-Parkin 신호기전은 미토파지 핵심 조절기전으로 보고되고 있다 (Chakravorty et al., 2019; Fang et al., 2019). 현재까지 보고된 연구결과에 따르면, PINK1은 정상적인 미토콘드리 아 막전위 상태에서 바로 제거되어 낮은 수준을 유지만, 비 정상적인 조건의 미토콘드리아에서는 막전위가 감소하면 PINK1이 발현이 증가되어 원형질에 존재하는 Parkin을 미 토콘드리아 외막으로 이동시켜 미토콘드리아에 존재하는 여 러 단백질을 유비퀴틴화 시켜 미토파지가 활성화된다 (Whitworth \& Pallanck, 2017). 유비퀴틴화 된 단백질은 오토파지의 어댑터 단백질인 sequestosome 1(p62)에 의해 인식되고 Microtubule-associated protein-1 light 
cahin-3(LC3-II)와 결합하여 비정상적인 미토콘드리아는 결국 분해된다(Pankiv et al., 2007; Kirkin et al., 2009).

본 연구에서도 미토파지의 개시인자인 PINK-1과 Parkin의 발현을 분석한 결과 NTC 집단과 비교하여 TC 집단에서 PINK-1은 유의하게 증가하였고, Parkin은 유 의하게 감소하였다. PINK-1의 발현이 증가한 것은 Chen \& Chan(2009)의 연구 결과와 일치하지 않았다. 미토파지의 특성상 정확한 해석은 어려우나 일반적으로 PINK-1이 Parkin을 동원시켜 미토파지 과정을 개시한 다는 가정하에 본 연구에서는 $\mathrm{AD}$ 로 인해 PINK-1의 발 현이 증가하였다. PINK-1의 발현 증가로 인해 미토파지 는 개시되었지만 Parkin의 발현이 감소하여 결과적으로 미토파지의 활성화되지 못한 것으로 생각된다. 하지만 트 레드밀 운동은 PINK-1을 유의하게 감소시키고, Parkin 은 유의하게 증가시켰다. Zhao et al.(2020)은 알츠하이 머 유전자 변형 생쥐를 대상으로 12 주간 트레드밀 운동 을 시킨 결과 PINK1의 감소와 Parkin의 증가를 보고하 여 본 연구결과와 일치하였다. 이러한 결과는 Parkin이 증가되어 미토파지 다음 과정을 유도하여 정상적인 기능 을 수행하였기 때문에 미토파지의 개시인자인 PINK-1의 발현은 감소된 것으로 생각할 수 있다. 하지만 PINK-1과 Parkin의 발현은 매우 복잡하고 발현 수준에 따라 다른 의미로 해석 될 수 있기 때문에 미토파지의 전반적인 해 석이 불가하다. 따라서 미토파지 이후 과정인 LC3-II/LC3-I ratio와 p62 발현 수준을 확인하였다.

p62는 오토파고좀을 형성할 때 비정상적인 소기관의 유입을 유도하며, 자가포식체 막에 붙어있는 LC3와 결합 한다. 결국 p62는 LC3와 유비퀴틴과 동시에 결합하면서 비정상적인 소기관의 최종 소멸을 유도하면서 오토파고 좀과 함께 분해되어 미토파지에 관여하는 것으로 보고되 었다(Bjorkoy et al., 2005). LC3는 분해와 합성으로 오 토파지의 flux를 확인하는 핵심 마커로 알려져 있으며, 오토파고좀(autophagosome)을 형성한다. 본 연구에서 LC3와 p62 발현을 확인한 결과 LC3-II/LC3-I ratio와 $\mathrm{p} 62$ 는 NTC 집단과 비교하여 $\mathrm{TC}$ 집단에서 유의하게 증 가된 것으로 나타났다. 이는 $\mathrm{AD}$ 생쥐의 뇌에서 LC3-II와 p62를 분석한 결과와 일치한다(Ye et al., 2015). 이러 한 결과는 PINK-1과 Parkin에 의해 미토파지가 개시되 지 않아 비정상적인 미토콘드리아가 축적되었다고 볼 수
있다. 그러나 트레드밀 운동을 실시한 TE 집단에서 유의 하게 감소된 것으로 나타났다. Kang \& Cho(2015)의 연 구에서도 알츠하이머 형질 전환 생쥐를 대상으로 12 주간 의 트레드밀을 운동시킨 결과 대뇌피질에서 LC3-II의 증 가와 $\mathrm{p} 62$ 의 감소가 나타난다고 보고하였다. 이는 트레드 밀 운동이 오토파고좀과 리소좀의 결합을 증가시켜 비정 상적인 미토콘드리아를 제거하는 미토파지의 기능이 활 성화되었다고 볼 수 있다.

운동은 미토콘드리아의 생합성 및 역동성을 개선시키 는 것으로 알려져 있다(Yan et al., 2012). 알츠하이머 질환에서 미토콘드리아 생합성과 관련된 가장 많이 연구 된 단백질 중 SIRT-1은 Sirtuin 계열로 PGC- $1 \alpha$ 를 탈아 세틸화하여 세포기능을 조절할 수 있으며, 에너지 관리, 노화 및 스트레스 반응을 포함한 다양한 과정에 관여한다 고 알려져 있다(Donmez, 2012; Lalla \& Donmez, 2013; Mitchell et al., 2014; Kaarniranta et al., 2018). 본 연구에서 SIRT- 1 과 그 하위기전인 PGC- $1 \alpha$, Tfam을 분석하였고, 전자전달계 핵심 효소인 COX-IV를 분석한 결과 NTC 집단과 비교하여 TC 집단에서 유의하 게 감소된 것으로 나타났지만, $\mathrm{TE}$ 집단에서는 $\mathrm{TC}$ 집단 에 비해 유의하게 증가하였다. Zhao et al.(2020)의 연 구에서도 $\mathrm{PGC}-1 \alpha$ 와 $\mathrm{TFAM}$ 의 수준이 알츠하이머 집단 보다 운동집단에서 유의하게 증가하여 본 연구결과와 일 치하였다. 또한, Koo \& Cho (2017)의 연구에서 신경퇴 행성 질환 중 하나인 파킨슨질환 동물을 대상으로 8주간 의 트레드밀 운동을 실시한 결과 SIRT- $1, \mathrm{PGC}-1 \alpha$, Tfam 및 $\mathrm{COX}-\mathrm{IV}$ 의 수준이 증가하였다고 보고하고 있 다. 따라서 미토콘드리아는 뉴런에 있는 발전소로서 $\mathrm{ATP}$ 의 주요 공급원으로 알츠하이머 유전자 변형 생쥐에 서 억제된 미토콘드리아 생합성이 운동을 통해 개선되었 음을 시사했다. 따라서 손상된 미토콘드리아 기능을 개선 시키는 것은 증가된 $\mathrm{A} \beta$ 를 감소시킬 수 있다고 생각할 수 있다.

인지기능의 감소는 $\mathrm{AD}$ 의 병리학적 특징으로 인지기능 을 개선을 위한 다양한 연구가 진행되고 있다. 특히 트레 드밀 운동은 신경퇴행성 질환뿐만 아니라 불안 및 우울증 과 같은 스트레스 증상의 동물에게도 긍정적인 인지기능 효과가 나타낸다고 보고되고 있다(Lapmanee 등, 2017). 본 연구에서도 12 주간의 트레드밀 운동이 인지기 
능에 미치는 영향을 확인하기 위해 수중미로검사를 실시 하였다. 먼저, TC 집단은 NTC 집단과 비교하여 수영 시 간과 거리가 유의하게 증가하였으나, 12 주간 트레드밀 운동을 실시한 $\mathrm{TE}$ 집단에서는 $\mathrm{TC}$ 집단과 비교하여 수영 시간과 수영 거리가 유의하게 감소하는 것으로 나타났다. 이는 TE를 통한 인지기능이 개선되었다는 간접적인 의미 로 해석될 수 있으며 $\mathrm{AD}$ 모델을 대상으로 운동을 통해 인 지기능의 개선을 보고한 선행연구와 일치하는 결과를 나 타냈다(Choi et al., 2014; Koo et al., 2017; Cho et al., 2010). 따라서, 장기간의 트레드밀 운동은 $\mathrm{AD}$ 생쥐 의 인지기능 감소를 일부 완화시킬 수 있는 효과적인 운 동이라고 생각된다.

\section{결론 및 제언}

본 연구는 트레드밀 운동에 대한 $\mathrm{AD}$ 의 병리학적 특징 인 $\mathrm{A} \beta$ 단백질 축적과 인지기능에 미치는 영향을 확인하 기 위해 $\mathrm{A} \beta$ 단백질 대사와 그 하위 기전을 확인하고 신경 세포사멸 수준을 확인하였다. 먼저 트레드밀 운동은 SIRT-1.PGC- $1 \alpha$ 기전을 증가시켜 $\mathrm{A} \beta$ 단백질 생성을 유 도하는 amyloidogenic pathway 관련 단백질 발현을 감 소시키고 생성을 억제하는 non-amyloidogenic pathway 관련 단백질을 증가시켜 $\mathrm{A} \beta$ 단백질 수준을 감 소시켰다. 마지막으로 트레드밀 운동에 의한 $\mathrm{A} \beta$ 단백질 감소는 신경세포사멸을 억제시켰으며 결과적으로 인지 기능의 개선을 유도한 것으로 나타났다. 이를 종합해 보 면 트레드밀 운동은 $\mathrm{A} \beta$ 대사를 조절할 수 있는 또 하나의 효과적인 운동 형태로 사람에게서 나타나는 트레드밀 운 동의 인지능력 개선 효과 기전을 구체적으로 밝힐 수 있 는 의미 있는 연구 결과라고 생각한다. 하지만 $\mathrm{A} \beta$ 대사를 조절하는 다양한 기전(인슐린 신호전달, 소포체 스트레 스, 오토파지, 미토콘드리아 기능)들이 존재하기 때문에 트레드밀 운동에 대한 보다 구체적인 기전연구가 필요하 다고 생각된다.

\section{참고문헌}

Bradford, M. M. (1976). A rapid and sensitive method for the quantitation of microgram quantities of protein utilizing the principle of protein-dye binding. Anal Biochem, 72, 248-54.

Bjorkoy, G., Lamark, T., Brech, A., Outzen, H., Perander, M., \& et al. (2005). p62/ SQSTM1 forms protein aggregates degraded by autophagy and has a protective effect on huntingtin-induced cell death. J Cell Biol, 171(4), 603-14.

Calkins, M. J., Manczak, M., Mao, P., Shirendeb, U., \& Reddy, P. H. (2011). Impaired mitochondrial biogenesis, defective axonal transport of mitochondria, abnormal mitochondrial dynamics and synaptic degeneration in a mouse model of Alzheimer's disease. Hum Mol Genet, 20, 4515 - 45296.

Chakravorty, A., Jetto, C. T., \& Manjithaya, R. (2019). Dysfunctional Mitochondria and Mitophagy as Drivers of Alzheimer's Disease Pathogenesis. Front Aging Neurosci. 11, 311.

Chan, D. C. (2006). Mitochondria: dynamic organelles in disease, aging, and development. Cell, 125(7):1241-52.

Chen, H., Chan, D. C. (2009). Mitochondrial dynamics--fusion, fission, movement, and mitophagy--in neurodegenerative diseases. Human Molecular Genetics, 18(R2), 169-176.

Cho, J. Y., Um, H. S., Kang, E. B., Cho, I. H., Kim, C. H., Cho, J. S., \& Hwang, D. Y. (2010). The combination of exercise training and alpha-lipoic acid treatment has therapeutic effects on the pathogenic phenotypes of Alzheimer's disease in NSE/APPsw-transgenic mice. Int J Mol Med, 25(3), 337-46.

Choi, A, M, Ryter, S. W., \& Levine, B. (2013). Autophagy in human health and disease. NEngl J Med, 368, 1845-1846.

Choi, D. H., Kwon, I. S., Koo, J. H., Jang, Y. C., Kang, E. B., Byun, J. E., Um, H. S., Park, H. S., Yeom, D. C., Cho, I. H., \& Cho, J. Y. (2014). The effect of treadmill exercise on inflammatory responses in rat model of streptozotocin-induced experimental dementia of Alzheimer's type. Journal of Exercise Nutrition \& Biochemistry, 18(2), 225-233.

Choi, S. H., Bylykbashi, E., Chatila, Z. K., Lee, S. W., Pulli, B., Clemenson, G. D., Kim, E., Rompala, A., Oram, M. K., Asselin, C., Aronson, J., Zhang, C., Miller, S. J., Lesinski, A., Chen, J. W., Kim, D. Y., van Praag, H., Spiegelman, B. M., Gage, F .H., \& Tanzi, R. E. (2018). Combined adult neurogenesis and BDNF mimic exercise effects on cognition in an Alzheimer's mouse model. Science, 361(6406), eaan8821.

Ding, W. X., \& Yin, X. M. (2012). Mitophagy: mechanisms, pathophysiological roles, and analysis. Biol Chem, 393, 547 - 
56.

Donmez, G. (2012). The Effects of SIRT1 on Alzheimer's Disease Models. Int J Alzheimers Dis, doi:10.1155/2012/509529

Fang, E. F., Hou, Y., Palikaras, K., Adriaanse, B. A., Kerr, J. S., Yang, B., Lautrup, S., Hasan-Olive, M. M., Caponio, D., Dan, X., Rocktäschel, P., Croteau, D. L., Akbari, M., Greig, N. H., Fladby, T., Nilsen, H., Cader, M. Z., Mattson, M. P., Tavernarakis, N., \& Vilhelm A. Bohr, V. A. (2019). Mitophagy inhibits amyloid- $\beta$ and tau pathology and reverses cognitive deficits in models of Alzheimer's disease. Nat Neurosci, 22(3), 401-412.

Gonçalves, I. O., Passos, E., Diogo, C. V., Rocha-Rodrigues, S., Santos-Alves, E., Oliveira, P. J., Ascensão, A., \& Magalhães, J. (2016). Exercise mitigates mitochondrial permeability transition pore and quality control mechanisms alterations in nonalcoholic steatohepatitis. Appl Physiol Nutr Metab, 41(3), 298-306.

Hansson Petersen, C. A., Alikhani, N., Behbahani, H., Wiehager, B., Pavlov, P. F., Alafuzoff, I., Leinonen, V., Ito, A., Winblad, B., Glaser, E. \& Ankarcrona, M. (2008). The amyloid beta-peptide is imported into mitochondria via the TOM import machinery and localized to mitochondrial cristae. Proc Natl Acad Sci USA, 105(35), 13145-50.

Ittner, L. M., \& Gotz, J. (2011). Amyloid-beta and tau - a toxic pas de deux in Alzheimer's disease. Nat Rev Neurosci, 12, 65-72.

Joselin, A. P., Hewitt, S. J., Callaghan, S. M., Kim, R. H., Chung, Y. H., Mak, T. W., Shen, J., Slack, R. S., \& Park, D. S. (2012). ROS-dependent regulation of Parkin and DJ-1 localization during oxidative stress in neurons. Hum Mol Genet, 21(22):4888-903.

Joshi, P. R., Vetterke, M., Hauburger, A., Tacik, P., Stoltenburg, G. \& Hanisch, F. (2014). Functional relevance of mitochondrial abnormalities in sporadic inclusion body myositis. J Clin Neurosci, 21(11):1959-63.

Kaarniranta, K., Kajdanek, J., Morawiec, J., Pawlowska, E., \& Blasiak, J. (2018). PGC-1alpha Protects RPE Cells of the Aging Retina against Oxidative Stress-Induced Degeneration through the Regulation of Senescence and Mitochondrial Quality Control. The Significance for AMD Pathogenesis, 19.

Kang, E. B., Cho, J. Y. (2015). Effect of treadmill exercise on PI3K/AKT/mTOR, autophagy, and Tau hyperphosphorylation in the cerebral cortex of NSE/htau23 transgenic mice. J Exerc Nutrition Biochem, 19(3), 199-209.
Kang, E. B., Kwon, I. S., Koo, J. H., Kim, E. J., Kim, C. H., Lee, J., Yang, C. H., Lee, Y. I., Cho, I. H. \& Cho, J. Y. (2013). Treadmill exercise represses neuronal cell death and inflammation during $A \beta$-induced ER stress by regulating unfolded protein response in aged presenilin 2 mutant mice. Apoptosis. 18(11), 1332-47.

Kelley, B. B., Yu, D., Weihong S. (2011). Morris water maze test for learning and memory deficits in Alzheimer's disease model mice. Journal of Visualized Experiments, 20;(53), 2920.

Khandelwal, P. J., Herman, A. M., Hoe, H. S., Rebeck, G. W., \& Moussa, C. E. (2011). Parkin mediates beclin-dependent autophagic clearance of defective mitochondria and ubiquitinated Abeta in $\mathrm{AD}$ models. Human Molecular Genetics, 20(11), 2091-102.

Kirkin, V., Lamark, T., Sou, Y. S., Bjørkøy, G., Nunn, J. L., Bruun, J. A., Shvets, E., McEwan, D. G., Clausen, T. H., Wild, P., Bilusic, I., Theurillat, J. P., Øvervatn, A., Ishii, T., Elazar, Z., Komatsu, M., Dikic, I., \& Johansen, T. (2009). A role for NBR1 in autophagosomal degradation of ubiquitinated substrates. Mol Cell, 33(4), 505-16.

Koo, J. H., Kang, E. B., Oh, Y. S., Yang, D. S., \& Cho, J. Y. (2017). Treadmill exercise decreases amyloid- $\beta$ burden possibly via activation of SIRT-1 signaling in a mouse model of Alzheimer's disease. Exp Neurol. 288, 142-152.

Koo, J. H., \& Cho, J. H. (2017). Treadmill Exercise Attenuates a -Synuclein Levels by Promoting Mitochondrial Function and Autophagy Possibly via SIRT1 in the Chronic MPTP/P-Induced Mouse Model of Parkinson's Disease. Neurotox Res, 32(3), 473-486.

Kumar, A., \& Singh, A. (2015). A review on mitochondrial restorative mechanism of antioxidants in Alzheimer's disease and other neurological conditions. Frontiers in Pharmacology, 6, 206.

Lalla, R., \& Donmez, G. (2013). The Role of Sirtuins in Alzheimer's Disease. Front Aging Neurosci, 9(5), 16.

Lapmanee, S., Charoenphandhu, J., Teerapornpuntakit, J., Krishnamra, N., \& Charoenphandhu, N. (2017). Agomelatine, venlafaxine, and running exercise effectively prevent anxietyand depression-like behaviors and memory impairment in restraint stressed rats. PLoS One, 12(11).

Lazarou, M., Sliter, D. A., Kane, L. A., Sarraf, S. A., Wang, C., Burman, J. L., Sideris, D. P., Fogel, A. I., \& Youle, R. J. (2015). The ubiquitin kinase PINK1 recruits autophagy receptors to 
induce mitophagy. Nature, 524, 309 - 314 .

Lira, V. A, Okutsu, M., Zhang, M., Greene, N. P., Laker, R. C., Breen, D. S., \& et al. (2013). Autophagy is required for exercise training-induced skeletal muscle adaptation and improvement of physical performance. FASEB J, 27(10), 4184-4193.

Lourenco, M. V., Frozza, R. L., de Freitas, G. B., Zhang, H., Kincheski, G. C., Ribeiro, F. C. et al. (2019). Exercise-linked FNDC5/irisin rescues synaptic plasticity and memory defects in Alzheimer's models. Nat Med 25, 165-175.

Luo, L., Dai, J. R., Guo, S. S., Lu, A. M., Gao, X. F., Gu, Y. R., Zhang, X. F., Xu, H. D., Wang, Y., Zhu, Z., Wood, L. J., \& Qin, Z. H. (2017). Lysosomal Proteolysis Is Associated With Exercise-Induced Improvement of Mitochondrial Quality Control in Aged Hippocampus. J Gerontol ABiol Sci Med Sci, 72(10), 1342-1351.

Manczak, M., Anekonda, T. S., Henson, E., Park, B. S., Quinn, J. \& Reddy, P. H. (2006). Mitochondria is a direct site of Aaccumulation in Alzheimer"s disease neurons: implications for free radical generation and oxidative damage in disease progression. Human molecular genetics, 15(9), 1437-1449.

Marques-Aleixo, I., Santos-Alves, E., Balca, M. M., Rizo-Roca, D., Moreira, P. I., Oliveira, P. J. \& et al. (2015). Physical exercise improves brain cortex and cerebellum mitochondrial bioenergetics and alters apoptotic, dynamic and auto(mito)phagy markers. Neuroscience, 301, 480-495

Marques-Aleixo, I., Santos-Alves, E., Balca, M. M., Moreira, P. I., Oliveira, P. J., Magalhaes, J.,\& et al. (2016). Physical exercise mitigates doxorubicin-induced brain cortex and cerebellum mitochondrial alterations and cellular quality control signaling. Mitochondrion, 26, 43-57

Mattson, M. P., \& Magnus, T. (2006). Ageing and neuronal vulnerability. Nature reviews Neuroscience, 7(4), 278-294.

Mitchell, S. J., Martin-Montalvo, A., Mercken, E. M., Palacios, H. H., Ward, T. M., Abulwerdi, G., Minor, R. K., Vlasuk, G. P., Ellis, J. L., Sinclair, D. A., Dawson, J., Allison, D. B., Zhang, Y., Becker, K. G., Bernier, M., \& de Cabo, R. (2014). The SIRT1 activator SRT1720 extends lifespan and improves health of mice fed a standard diet. Cell reports, 6, 836-843.

Naudi, A., Jove, M., Ayala, V., Cassanye, A., Serrano, J., Gonzalo, H., Boada, J., Prat, J., Portero-Otin, M. \& Pamplona, R. (2012). Cellular dysfunction in diabetes as maladaptive response to mitochondrial oxidative stress. Exp Diabetes Res, 696215.
Nichol, K. E., Parachikova, A. I., \& Cotman, C. W. (2007). Three weeks of running wheel exposure improves cognitive performance in the aged Tg2576 mouse. Behav Brain Res, 184(2), 124-32.

Pankiv, S., Clausen, T. H., Lamark, T., Brech, A., Bruun, J. A., Outzen, H., Øvervatn, A., Bjørkøy, G., \& Johansen, T. (2007). p62/SQSTM1 binds directly to Atg8/LC3 to facilitate degradation of ubiquitinated protein aggregates by autophagy. J Biol Chem, 282(33), 24131-45.

Reeve, A. K., Krishnan, K. J. \& Turnbull, D. M. (2008). Age related mitochondrial degenerative disorders in humans. Biotechnol $J$, 3(6), 750-6.

Rosales-Corral, S., Acuna-Castroviejo, D., Tan, D.X., López-Armas, G., Cruz-Ramos, J., Munoz, R., Melnikov, V. G., Manchester, L. C. \& Reiter, R. J. (2012). Accumulation of exogenous amyloid-beta peptide in hippocampal mitochondria causes their dysfunction: a protective role for melatonin. Oxid Med Cell Longev, 843649.

Rosen, K. M., Moussa, C. E., Lee, H. K., Kumar, P., Kitada, T., Qin, G., Fu, Q., \& Querfurth, H. W. (2010). Parkin reverses intracellular beta-amyloid accumulation and its negative effects on proteasome function. Journal of Neuroscience Research, 88(1), 167-78.

Sanchez-Alvarez, R., Martinez-Outschoorn, U. E., Lamb, R., Hulit, J., Howell, A., Gandara, R., Sartini, M., Rubin, E., Lisanti, M. P. \& Sotgia, F. (2013). Mitochondrial dysfunction in breast cancer cells prevents tumor growth: understanding chemoprevention with metformin. Cell Cycle, 12(1):172-82.

Selkoe, D. J. (2001). Alzheimer's disease: genes, proteins, and therapy. Physiological reviews. 81, 741-766.

Swerdlow, R. H. (2018) Mitochondria and mitochondrial cascades in Alzheimer's disease. J Alzheimers Dis, 62, 1403-1416.

Tanzi, R. E. \& Bertram, L. (2005). Twenty years of the Alzheimer's disease amyloid hypothesis: a genetic perspective. Cell, 120, 545-555.

Vainshtein, A., Tryon, L. D., Pauly, M., \& Hood, D. A. (2015). The role of PGC-1a during acute exercise-induced autophagy and mitophagy in skeletal muscle. Am J Physiol Cell Physiol, 308(9), C710-9.

Wang, L., Pu, Z. Li, M., Wang, K., Deng, L., \& Chen, W. (2020). Antioxidative and antiapoptosis: Neuroprotective effects of dauricine in Alzheimer's disease models. Life Sciences, 3205(19), 31165-8. 
Whitworth, A. J, \& Pallanck, L. J. (2017). PINK1/Parkin mitophagy and neurodegeneration-what do we really know in vivo? Curr Opin Genet Dev. 44, 47-53.

Wilkins, H. M., \& Swerdlow, R. H. (2018). Amyloid Precursor Protein Processing and Bioenergetics. Brain Res Bull, 2133 : $71-79$.

Yan, Z., Lira, V. A., \& Greene, N. P. (2012). Exercise training-induced regulation of mitochondrial quality. Exercise and Sport Scienece Reviews, 40(3), 159-164.

Yao, J., Irwin, R. W., Zhao, L., Nilsen, J., Hamilton, R. T., \& Brinton, R. D. (2009) Mitochondrial bioenergetic deficit precedes Alzheimer's pathology in female mouse model of Alzheimer's disease. Proc Natl Acad Sci USA, 106, 14670 14675.
Ye, X., Sun, X., Starovoytov, V., \& Cai, Q. (2015). Parkin-mediated mitophagy in mutant hAPP neurons and Alzheimer's disease patient brains. Hum Mol Genet, 24, 2938 - 2951

Youle, R. J. \& van der Bliek, A. M. (2012). Mitochondrial fission, fusion, and stress. Science, 337(6098), 1062-1065.

Zhao, N., Yan, Q. W., Xia, J., Zhang, X. L., Li, B. X., Yin, L. Y., \& $\mathrm{Xu}$, B. (2020). Treadmill Exercise Attenuates Aß-Induced Mitochondrial Dysfunction and Enhances Mitophagy Activity in APP/PS1 Transgenic Mice. Neurochem Res, 45(5), 1202-1214.

Zhao, N., Zhang, X., Song, C., Yang, Y., He, B., \& Xu, B. (2018). The effects of treadmill exercise on autophagy in hippocampus of APP/PS1 transgenic mice. Neuroreport, 29(10), 819 - 825. 


\title{
트레드밀 운동이 알츠하이머 질환의 미토콘드리아 항상성 기전에 미치는 영향
}

\author{
최동훈 ${ }^{1}$, 권기천 ${ }^{2}$, 엄현섭 $^{3}$, 오은택 ${ }^{4}$, 조준용 ${ }^{5}$ \\ 1한국체육대학교 박사 \\ 2한국체육대학교 박사수료 \\ 3건양대학교 교수 \\ ${ }^{4}$ 우송대학교 교수 \\ ${ }^{5}$ 한국체육대학교 교수
}

[목적〕 본 연구는 알츠하이머(alzheimer's disease: AD) 형질전환 생쥐를 대상으로 12 주간의 트레드밀 운동이 미토콘드리아 항상성 기전에 미치는 영향을 확인하기 위해 미토파지와 미토콘드리아 생합성 관련 단백 질을 분석하여 이를 통해 $\mathrm{AB}$ 감소와 인지기능이 개선되는지 확인하는데 있다. 〔방법〕 실험동물은 non-tg-control(NTC, n=10), tg-control(TC, n=10) 및 tg-exercise(TE, n=10)으로 구분하고, 트레 드밀 운동은 12 주간 실행하였다 $(15 \mathrm{~m} / \mathrm{min}, 60 \mathrm{~min}, 5 \mathrm{times} / \mathrm{week})$. 운동 후 인지기능 능력을 확인하기 위 해 수중미로검사를 실시하고, $\mathrm{AD}$ 의 병리학적 특징인 아밀로이드 단백질, 신경세포사멸 및 미토콘드리아 항상 성 기전(미토파지, 미토콘드리아 생합성)에 관련된 단백질들을 western blot과 immunohistochemistry를 통해 확인하였다. 〔결과) 그 결과, 트레드밀 운동은 올리고머 아밀로이드를 유의하게 감소시켰고, 세포사멸과 관련된 단백질(PUMA, Bax, Bcl-2)에도 긍정적인 효과를 나타냈다. 또한, 트레드밀 운동을 통해 PINK-1 은 감소하고, parkin을 증가시켜 미토파지의 활성 억제가 일부 완화된 것으로 나타났다. 오토파지 핵심 마커 인 LC3와 p62는 TC 집단에 비해 TE 집단에서 $\mathrm{p} 62$ 발현을 유의하게 감소시키고, LC3-II/LC3-I ratio은 유의하지는 않지만 감소하는 경향이 나타나 미토파지의 활성을 증가시킨 것으로 확인되었다. 미토콘드리아 생 합성과 관련된 단백질(SIRT-1, PGC- $1 \mathrm{a}$, Tfam 및 COX-IV)을 확인한 결과 트레드밀 운동을 통해 모든 단 백질들의 발현이 일부 증가되는 것을 확인하였다. 마지막으로, 인지능력은 트레드밀 운동을 통해 수영 거리와 시간 모두 단축시켜 인지능력이 향상된 것으로 나타났다. ‘결론) 따라서 트레드밀 운동은 $\mathrm{AD}$ 의 병리학적 특 징인 아밀로이드 단백질의 수준을 감소시키고 미토파지의 활성과 미토콘드리아 기능향상을 유도하여 결과적으 로 인지기능의 개선을 유도할 수 있는 효과적인 방법이라고 생각된다.

주요어: 인지기능, 아밀로이드, 미토파지, 미토콘드리아 생합성, 세포사멸 